\title{
Kisspeptins: New Local Modulators of Testis Activity
}

\author{
Rosaria Meccariello* \\ *Dipartimento di Scienze Motorie e del Benessere \\ Università di Napoli Parthenope, via Medina 40, 80133 Napoli Italy. \\ rosaria.meccariello@uniparthenope.it
}

Keywords: kisspeptin, Gpr54, spermatogenesis, reproduction, $H P G$ axis

\begin{abstract}
Spermatogenesis, the process that leads the production of male gametes, consists in the progression of mitotic spermatogonia toward meiosis and spermiogenesis in order to produce functional spermatozoa. This complex process requires a deep network among a wide set of endocrine, paracrine and autocrine factors exerting their activity at different levels along the hypothalamus-pituitary-gonad (HPG) axis. The upstream activity of hypothalamic Gonadotropin Releasing Hormone (GnRH) is followed by the secretion of pituitary gonadotropins [Follicle stimulating hormone (FSH) and Luteinizing Hormone (LH)] which in turn promote testosterone biosynthesis from the testis. Such an endocrine route is locally integrated by several local modulators that ensure the progression of the spermatogenesis through the fine communications among germ cells and somatic cells - interstitial Leydig cells and nurse Sertoli cells in the germinal epithelium-.

In 1996 the discovery of KiSSI gene as a metastasis suppressor gene followed by the characterization of a kisspeptin receptor Gpr54 not only added insights in cancer biology, but surprisingly opened a new scenario in the neuroendocrine and local control of reproduction [1]. At present, kisspeptin system has been characterized from fish to mammals and multiple kiss and Gpr54 genes have been detected in non mammalian vertebrates [2].
\end{abstract}

Kisspeptin family comprises a set of multifunctional peptides sharing a common RF-amide motif in their C-terminal region that have the ability to activate Gpr54, a typical G coupled receptor located on cell membrane. All Kisspeptins originate from the cleavage of a 145 precursors encoded by the gene kiss 1 and are commonly known as kisspeptin-54, -13, -14 and -10 [Oakley et al. 2009]. Nowadays kisspeptin signalling via Gpr54 represents the main controller of HPG axis. In fact, it modulates the activity of GnRH neurons affecting gonadotropin secretion and steroid biosynthesis, and mediates sex steroid dependent feedback mechanisms [3]. Lifestyle and environmental cues positively or negatively modulate reproductive health affecting HPG axis. In this respect, many environmental (i.e photoperiodic), stressor and nutritional cues just convey on kisspeptin neurons located in the hypothalamic arcuate and anteroventral-periventricular nuclei in order to modulate GnRH activity and reproductive functions [3-4]. The key role of kisspeptin system in the modulation of HPG axis is confirmed by clinical studies in which impairment of kisspeptin signalling causes hypogonadotropic hypogonadism or, by contrast, its upregulation leads to precocious puberty [5-7]. Consistently, in mammalian and non mammalian vertebrates a wide set of studies confirmed the importance of kisspeptin signalling for the functionality of HPG axis, the timing of puberty onset and sex maturation $[3,8-9]$.

The exogenous administration of kisspeptin exerts different activity on reproduction, from testis degeneration [10] to stimulation or hyperstimulation of HPG axis [11-12], depending on kisspeptin dose, treatment duration and route of administration. However, all these effects were suggested to be centrally mediated. In spite of the well known kisspeptin activity in the hypothalamus, in the last months the importance of local kisspeptin activity also emerged. In fact, kisspeptin and Gpr54 (mRNA or protein) have been detected also in the testis providing evidence of the requirement of their local activity to gain a successful spermatogenesis [13]. Morphological and molecular data address the presence of kisspeptin and/or Gpr54 primarily in Leydig and germ cells in vertebrates, with 
differences related to age, species, and methodology [13]. Besides local kisspeptin activity, the secretion of kisspeptin produced by testis has been recently demonstrated in mouse [14]. However, beside the localization and the aforementioned observations, in testis explants and in immortalized or primary Leydig cell culture kisspeptin does not affect steroid biosynthesis [15-16]. By contrast, in rhesus monkey direct effect on testosterone biosynthesis has been demonstrated [17].

New local functions of kisspeptin system recently came from studies conducted in a seasonal breeder with testis cystic organization, the anuran amphibian Pelophylax esculentus (previously knows as Rana esculenta), once again confirming the deep contribute of non mammalian vertebrates in the discovery of master systems in reproductive endocrinology [18]. In this seasonal breeder spermatogenesis starts during late winter-spring with mitotic division of spermatogonia and proceeds during summer with meiotic events; in autumn massive spermiogenesis occurs followed by the winter stasis in which the testis simply contains quiescent primary spermatogonia and newly formed spermatozoa attached to Sertoli cells. During the annual cycle of P. esculentus, Gpr54 fluctuates and is expressed in both Leydig cells and mitotic spermatogonia [19]. Furthermore, in spite no kiss gene has been cloned or characterized in this experimental model, kisspeptin signalling locally induces a wide set of events critical for the upsurge of spermatogenesis onset and the progression of spermatogenesis [20] (Figure 1). In fact, at the onset of a new reproductive cycle, Kp-10 administration in ex vivo testis is accomplished by i) the increase of the number of tubules containing cysts of mitotic stages in parallel to the decrease of empty tubules containing quiescent spermatogonia and spermatozoa only [20]; ii) the increased expression of PCNA (Proliferating Cell Nuclear Antigen), a well known marker of DNA biosynthesis during cell cycle [20], iii) the increased expression of local GnRH/GnRH receptors and estrogen receptors (ER) $\alpha$ and $\beta$ [19-20], two master signalling systems strongly involved in the recruitment of quiescent spermatogonia for proliferation [21]. In addition, the existence of mutual enhancement between kisspeptin and estradiol may be suggested since Kp-10 increases the expression of ER $\alpha / \beta$ and $17 \beta$-estradiol increases the expression rate of Gpr54 [19-20] (Figure 2). Similarly than frog, also in mouse the expression profile of kiss 1 and $E R \alpha$ fully parallel during postnatal testis development [16]. Consistently, in hypothalamic GT1-7 cell lines kisspeptin induces the expression of $E R \alpha$ and $E R \beta$, whereas estradiol induces that of Gpr54 [22].

\section{In vitro treatment}

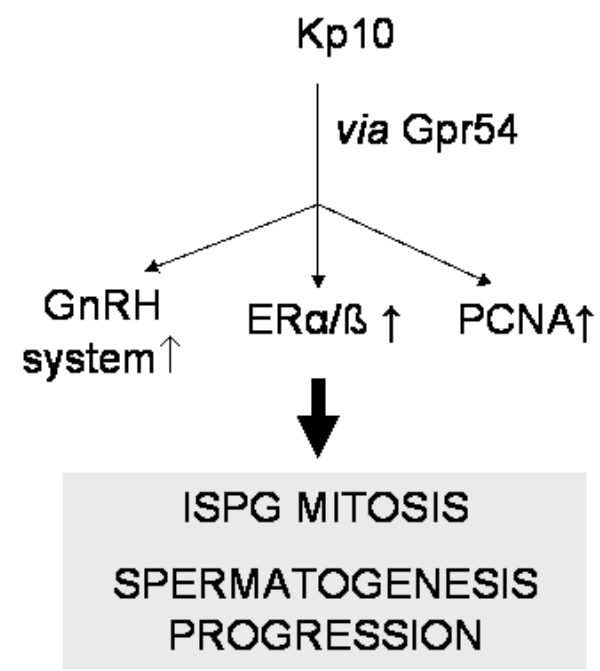

Figure1. In vitro effects of Kp-10 on frog spermatogenesis at the end of the winter stasis.

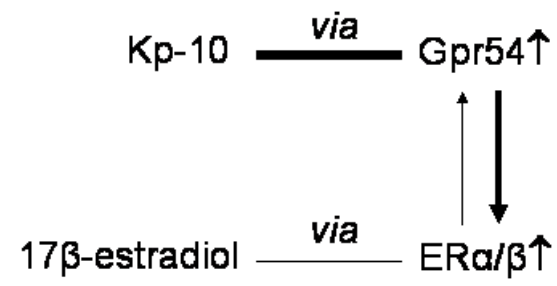

Figure2. Mutual enhanced activity of Kp-10 and $17 \beta$-estradiol on the expression of ER $\alpha / \beta$ and Gpr54 respectively in frog testis. 
Lastly, the expression of kisspeptin system has also been reported in post meiotic germ cells [Meccariello 2013]. In particular, in human kisspeptin signalling affects sperm motility [23] and lower plasma levels of kisspeptin have been observed in infertile males as compared to fertile males [24-25]. Also mouse spermatozoa express Gpr54 in acrosomal region and $\mathrm{Kp}-10$ treatment increases sperm intracellular concentration of $\mathrm{Ca}^{2+}$. Interestingly, kisspeptin signalling seems to modulate spermatozoa transit in male reproductive tract and kisspeptin antagonist Kp-234 impairs the fertilization capacity of spermatozoa in in vitro fertilization [26], once again confirming the importance of local kisspeptin signalling for reproduction.

Taking in account the above considerations, kisspeptin locally modulates different aspect of male reproduction, from spermatogenesis progression to the aquisition of sperm functions. Hence, the discovery of impaired kisspeptin activity in infertile men, candidates this signalling system as a new therapeutic tool for the treatment of infertility.

\section{REFERENCES}

[1]. Oakley A.E., Clifton D.K. and Steiner R.A., Kisspeptin signaling in the brain. Endocr. Rev. 30, 713-743, (2009).

[2]. Lee Y.R., Tsunekawa K., Moon M.J., Um H.N., Hwang J.I., Osugi T., Otaki N., Sunakawa Y., Kim K., Vaudry H., Kwon H.B., Seong J.Y. and Tsutsui K., Molecular evolution of multiple forms of kisspeptins and Gpr54 receptors in vertebrates. Endocrinol. 150, 2837-2846 (2009).

[3]. Pinilla L., Aguilar E., Dieguez C., Millar R.P. and Tena-Sempere M., Kisspeptins and reproduction: physiological roles and regulatory mechanisms. Physiol. Rev. 92, 1235-1316 (2012).

[4]. Karamikheirabad M., Behzadi G., Faghihi M., Raoofian R., Ejtemaei Mehr S., Zuure W.A. and Sadeghipour H.R., A role for endocannabinoids in acute stress-induced suppression of the hypothalamic-pituitary-gonadal axis in male rats. Clin. Exp. Reprod. Med. 40, 155-162 (2013).

[5]. de Roux N., Genin E., Carel J.C., Matsuda F., Chaussain J.L. and Milgrom E., Hypogonadotropic hypogonadism due to loss of function of the KiSS1-derived peptide receptor Gpr54. Proc. Natl. Acad. Sci. USA 100, 10972-10976 (2003).

[6]. Seminara S.B., Messager S., Chatzidaki E.E., Thresher R.R., Acierno J.S., Shagoury J.K., BoAbbas Y., Kuohung W., Schwinof K.M., Hendrick A.G., Zahn D., Dixon J., Kaiser U.B., Slaugenhaupt S.A., Gusella J.F., O'Rahilly S., Carlton M.B., Crowley W.F. Jr, Aparicio S.A. and Colledge W.H. The Gpr54 gene as a regulator of puberty. N. Engl. J. Med. 349, 1614-1627 (2003).

[7]. Ratnasabapathy R. and Dhillo W.S. , The effects of kisspeptin in human reproductive function therapeutic implications. Curr. Drug Targets 14(3), 365-371 (2013).

[8]. d'Anglemont de Tassigny X., Fagg L.A., Dixon J.P., Day K., Leitch H.G., Hendrick A.G., Zahn D., Franceschini I., Caraty A., Carlton M.B., Aparicio S.A. and Colledge W.H., Hypogonadotropic hypogonadism in mice lacking a functional Kiss1 gene. Proc. Natl. Acad. Sci. USA 104, 10714-10719 (2007).

[9]. Tena-Sempere M., Felip A., Gomez A., Zanuy S., Carillo M., Comparative insights of the kisspeptin/kisspeptin receptor system: lessons from nonmammalian vertebrates. Gen. Comp. Endocrinol. 175,234-243 (2012).

[10]. Ramzan F. and Qureshi I.Z., Intraperitoneal kisspeptin-10 administration induces dosedependent degenerative changes in maturing rat testes. Life Sci. 88(5-6), 246-256 (2011).

[11]. Thompson E.L., Murphy K.G., Patterson M., Bewick G.A., Stamp G.W., Curtis A.E., Cooke J.H., Jethwa P.H., Todd J.F., Ghatei M.A. and Bloom S.R., Chronic subcutaneous administration of kisspeptin-54 causes testicular degeneration in adult male rats. Am. J. Physiol. Endocrinol. Metab. 291(5), E1074-1082 (2006).

[12]. Thompson E.L., Amber V., Stamp G.W., Patterson M., Curtis A.E., Cooke J.H., Appleby G.F., Dhillo W.S., Ghatei M.A., Bloom S.R. and Murphy K.G., Kisspeptin-54 at high doses acutely induces testicular degeneration in adult male rats via central mechanisms. Br. J. Pharmacol. 156(4), 609-625 (2009). 
[13]. Meccariello R., Chianese R., Chioccarelli T., Ciaramella V., Fasano S., Pierantoni R. and Cobellis G., Intra-Testicular Signals Regulate Germ Cell Progression and Production of Qualitatively Mature Spermatozoa in Vertebrates. Front. Endocrinol. (Lausanne) 5, 69 (2014).

[14]. Salehi S., Adeshina I., Chen H., Zirkin B.R., Hussain M.A., Wondisford F., Wolfe A. and Radovick S., Developmental and endocrine regulation of kisspeptin expression in mouse Leydig cells. Endocrinol. 156, 1514-1522 (2015).

[15]. Mei H., Doran J., Kyle V., Yeo S.H. and Colledge W.H. Does Kisspeptin Signaling have a Role in the Testes? Front. Endocrinol. (Lausanne) 4, 198 (2013).

[16]. Wang J.Y., Hsu M.C., Tseng T.H., Wu L.S., Yang K.T. and Chiu C.H., Kisspeptin expression in mouse Leydig cells correlates with age. J. Chin. Med. Assoc. 78(4), 249-57 (2015).

[17]. Irfan S., Ehmcke J., Wahab F., Shahab M. and Schlatt S. Intratesticular action of kisspeptin in rhesus monkey (Macaca mulatta). Andrologia 46, 610-617 (2014).

[18]. Chianese R., Chioccarelli T., Cacciola G., Ciaramella V., Fasano S., Pierantoni R., Meccariello R. and Cobellis G., The contribution of lower vertebrate animal models in human reproduction research. Gen Comp Endocrinol 171:17-27 (2011).

[19]. Chianese R., Ciaramella V., Fasano S., Pierantoni R. and Meccariello R., Kisspeptin Receptor, Gpr54, as a candidate for the regulation of testicular activity in the frog, Rana esculenta. Biol. Reprod. 88, 73 (2013).

[20]. Chianese R., Ciaramella V., Fasano S., Pierantoni R. and Meccariello R., Kisspeptin drives germ cell progression in the anuran amphibian Pelophylax esculentus. Gen. Comp. Endocrinol. 211:81-91 (2015).

[21].Pierantoni R., Cobellis G., Meccariello R. and Fasano S., Evolutionary aspects of cellular communication in the vertebrate hypothalamo-hypophysio-gonadal axis. Int. Rev. Cytol. 218, 69-141 (2002).

[22]. Terasaka T., Otsuka F., Tsukamoto N., Nakamura E., Inagaki K., Toma K., Ogura-Ochi K., Glidewell-Kenney C., Lawson M.A. and Makino H., Mutual interaction of kisspeptin, estrogen and bone morphogenetic protein-4 activity in GnRH regulation by GT1-7 cells. Mol. Cell. Endocrinol. 381(1-2), 8-15 (2013).

[23]. Pinto F.M., Cejudo-Romàn A., Ravina C.G., Ferna`ndez-Sa`nchez M., Martin-Lozano D., Illanes M., Tena-Sempere M. and Candenas M.L., Characterization of the kisspeptin system in human spermatozoa. Int. J. Androl. 35, 63-73 (2012).

[24]. Kotani M., Katagiri F., Hirai T. and Kagawa J., Plasma kisspeptin levels in male cases with hypogonadism. Endocr. J. 61(11), 1137-40 (2014).

[25].Ramzan M.H., Ramzan M., Ramzan F., Wahab F., Jelani M., Khan M.A. and Shah M., Insight into the serum kisspeptin levels in infertile males. Arch. Iran Med. 18(1), 12-7 (2015).

[26].Hsu M.C., Wang J.Y., Lee Y.J., Jong D.S., Tsui K.H. and Chiu C.H., Kisspeptin modulates fertilization capacity of mouse spermatozoa. Reprod. 147, 835-845 (2014).

\section{AUTHOR's BIOGRAPHY}

Dr Meccariello, got her Degree in Biology at the University of Naples Federico II Italy and the Ph.D in Comparative Endocrinology at the University of Padova Italy in 1997 and 2004 respectively. Currently, she is Associate Professor of Biology at the Department of Movement Sciences and Wellness at Parthenope University of Naples, Italy. She has published 52 full-length papers in various peer-reviewed international journals. Recently she was Lead Guest editor of the Special Issue of International Journal of Endocrinology entitled "Endocannabinoids and Reproduction" and Guest Associate Editor of the e-book of Frontiers in Experimental Endocrinology entitled "Modulators of hypothalamic-pituitary-gonadal axis for the control of spermatogenesis and sperm quality in vertebrates". She is an expert in biology of reproduction, spermatogenesis, hypothalamus-pituitarygonad axis, central and local activity of GnRH, endocannabinoid and kisspeptin systems. 